\title{
Comparative Study of Different Blending Methods Used for Biodiesel Synthesis by Transesterification
}

\begin{abstract}
STEFAN SANDRU*, ION ONUTU
Petroleum-Gas University of Ploiesti, Department of Petroleum Engineering and Environmental Protection, 39 Bucharest Blv., 100520, Ploiesti, Romania

The first part of this study analyzed how the blending type of the components used in biodiesel synthesis through transesterification influences yield and the physical properties of the biodiesel. The second part of this study emphasized the way the added proportions of the synthesized biodiesel samples influenced the final diesel-biodiesel blend. This study concluded that the ultrasonic mixing method could replace classical mechanical mixing by being similar both in terms of yield and physical properties.
\end{abstract}

Keywords: ultrasonic biodiesel, diesel-biodiesel blends

\begin{abstract}
Climate change has brought to light diesel fuels and their negative influence on the environment, finding an ecological solution being a necessity. Biodiesel fuel, also known as FAME (Fatty Acid Methyl Esters), represents an alternative to fossil diesel fuels. One of the most common method used to synthesize biodiesel is base catalyst transesterification, due to reduced costs [1-4]. The classical method of transesterification involves mechanical blending of animal or vegetable oil with methanol or ethanol in the presence of a base, acid or enzyme catalyst for a few hours at a temperature having values established in the range $45^{\circ} \mathrm{C}-65^{\circ} \mathrm{C}$. This temperature is usually obtained by standard heating methods, using electrical resistances or heated oil baths. The time necessary for heating can be reduced by replacing classical heating with microwave heating, and the time needed for mixing can be reduced by replacing mechanical stirring with ultrasound blending. These aspects are confirmed by numerous scientific articles that mention not only the reduced time necessary for blending, butalso an increased yield of biodiesel from $50 \%$ to almost $90 \%$. Following studies by Subhedar P. et al. on biodiesel synthesized from sunflower oil using ultrasounds, they have been found to suppress the need for excess methanol [5] and shortens the time required for the reaction, increasing the yield, which is necessary when it comes to enzymatic interesterification using a lipase catalyst [6]. A similar study, on lipase catalyst and canola oil as raw material, was carried out by Bhangu et al. concluding that ultrasound has reduced the reaction time from 22-24 hours to 1 hour [7]. Santin et al. also confirms, in his studies, a $26 \%$ increase in yield when ultrasound is used to obtain biodiesel from soybean oil and macauba fruit oil with enzyme catalyst [8]. Sivaramakrishnan et al. tested the effect of ultrasounds on three types of catalysts: acids, basics and enzymes in the production of biodiesel from microalgae. The authors concluded that ultrasounds increase yield and shorten the duration of mixing, but additional studies are needed on the economic side involving this new blending method, in order to use them at a large industrial scale [9]. Utilizing used cooking oil, Refaat et al. achieved a $99 \%$ yield using ultrasound, having a methanol/oil molar ratio of $6 / 1$, using $\mathrm{KOH}$ as catalyst, the reaction taking place at $65^{\circ} \mathrm{C}$. He also stated that the time required for decanting had dropped from $8 \mathrm{~h}$ to 25 minutes [10]. The Masri et al. led studies aimed to test a new catalyst, concluding that no matter the blending
\end{abstract}

method, the existing differences are inconsequential [11]. Martinez-Guerra etal. used ultrasound in combination with microwaves to synthesize biodiesel from microalgae biomass as raw material. This experiment aimed to optimize the parameters required for the reaction, achieving a yield of $48.2 \%$. Using the classic heating and mixing techniques, the reaction time would have been much higher, which would negatively affect the yield [12]. In J oshi et al. study, ultrasounds had the role of enhancing karanja oil esterification with an acid catalyst in order to be used for the production of biodiesel. An increase of $10 \%$ yield in the synthesis of biodiesel using ultrasound esterified oil has been observed [13]. There are also multiple reviews of biodiesel synthesized by ultrasound. These reviews have analyzed the influence of factors such as: sonication frequency and its power, the raw material used, the catalysts used, molar ratios of oil/methanol or oil/ethanol concerning the time required for mixing and yield. Following reviews, similar conclusions were reached: ultrasound improves yield and shortens mixing time required for complete transesterification [14-16].

This paper aims at emphasizing the differences and similarities between the two types of blending used at synthesizing biodiesel by transesterification: mechanical stirring and ultrasound blending, as well as the manner the synthesized biodiesel samples influence the physical properties of the final blend between diesel and biodiesel.

\section{Experimental part}

Three original samples of biodiesel were synthesized by transesterification for this study: the first biodiesel type was synthesized using mechanical stirring, the second biodiesel type used ultrasound blending at $37 \mathrm{kHz}$ frequency and the third biodiesel type used ultrasound at $80 \mathrm{kHz}$ frequency. Both frequencies were set at 100W power. For the biodiesel synthesized by mechanical stirring it was used a discontinuous reactor that heated the samples using a water bath, the mixing being carried out by a stirring propeller. An ultrasonic bath, Elmasonic $\mathrm{P} 30 \mathrm{H}$, was used for the biodiesel synthesized with ultrasounds, this one also a discontinuous reactor, the sample heating being carried out in a water bath, too. Rapeseed oil was selected as the raw material for all three biodiesel samples, as Romania is one of the biggest producers of this feed, to be used for biodiesel [17]. 
Table 1

PHYSICAL PROPERTIES OF THE SAMPLES

\begin{tabular}{|c|c|c|c|c|c|c|}
\hline Sample Test & $\begin{array}{c}\text { Test } \\
\text { method }\end{array}$ & Unit & $\begin{array}{c}\text { Hydrofining } \\
\text { diesel }\end{array}$ & $\begin{array}{c}\text { Biodiesel- } \\
\text { mechanical } \\
\text { stirring }\end{array}$ & $\begin{array}{c}\text { Biodiesel- } \\
\text { ultrasound 37 } \\
\mathbf{k H z}\end{array}$ & $\begin{array}{c}\text { Biodiesel- } \\
\text { ultrasound 80 } \\
\mathbf{k H z}\end{array}$ \\
\hline $\begin{array}{c}\text { Relative density at } \\
\mathbf{2 0} \mathbf{0}^{\circ} \mathrm{C}\end{array}$ & $\begin{array}{c}\text { ISO } \\
3507: 1999 / \\
\text { ISO } \\
4787: 2010\end{array}$ & - & 838 & 882 & 885 & 883 \\
\hline $\begin{array}{c}\text { Kinematic viscosity } \\
\text { at 40 } \mathbf{4} \mathrm{C}\end{array}$ & $\begin{array}{c}\text { EN ISO } \\
3104\end{array}$ & $\mathrm{cSt}$ & 2.8 & 4.5 & 4.6 & 4.6 \\
\hline Flash point & $\begin{array}{c}\text { EN ISO } \\
2719\end{array}$ & ${ }^{\circ} \mathrm{C}$ & 78 & 176 & 174 & 174 \\
\hline Aniline point & $\begin{array}{c}\text { ASTM D } \\
611\end{array}$ & ${ }^{\circ} \mathrm{C}$ & 65.25 & -13 & -13 & -13 \\
\hline Diesel Index & $\begin{array}{c}\text { STAS 50- } \\
59\end{array}$ & - & 54.40 & 2.41 & 2.38 & 0.90 \\
\hline Lubricity & $\begin{array}{c}\text { EN IS0 } \\
12156-1\end{array}$ & $\mu m$ & 200 & 95.5 & 99.5 & 118 \\
\hline
\end{tabular}

In order to compare the three types of biodiesel, the same quantities and temperatures were maintained, as well as the same type of oil, its provenience being the same, that is parcel 86. The synthesis parameters for biodiesel were:

$-80 \mathrm{~g}$ of methanol +2 grams of $\mathrm{KOH}+200 \mathrm{~g}$ of rapeseed oil, with the methanol :oil molar ratio of 3.7:1;

-mixing temperature: $50^{\circ} \mathrm{C}$;

-mixing time: $2 \mathrm{~h}$ for mechanical stirring; $15 \mathrm{~min}$ for ultrasound blending at $37 \mathrm{kHz}$ frequency; 30 min for ultrasound blending at $80 \mathrm{kHz}$ frequency;

-separating biodiesel from glycerine will be carried out by decantation at room temperature, for $24 \mathrm{~h}$.

The time used for ultrasonic blending, in this study, was different from the time found in scientific articles, in order to ensure the complete accomplishment of transesterification reaction. Also, the blending duration was selected to be the minimum time required to obtain a biodiesel that fulfils the requirements of EN 14214.

In the second part of this paper it was studied the influence of biodiesel samples on the physical properties of the final diesel-biodiesel blend [18, 19]. To determine the manner in which the three types of biodiesel influence the physical properties of the final formulated blend between diesel and biodiesel, 36 original fuel mixtures were obtained. The fuel mixtures were obtained by mixing hydrofining diesel with each type of biodiesel with the following percentage concentrations ( $\%$ wums $): 1 \%, 3 \%, 6 \%$, $9 \%, 12 \%, 15 \%, 18 \%, 20 \%, 30 \%, 50 \%, 70 \%, 80 \%$ [20]. The new values, obtained as a result of characterizing mentioned blends, will be presented in graphics, along with the pure samples (diesel and biodiesel), to underline the influences of biodiesel on the final blend.

Articles on the chosen properties for this study were also published in literature: relative density at $20^{\circ} \mathrm{C}[21$, 22], kinematic viscosity at $40^{\circ} \mathrm{C}$ [21-25], flash point, aniline point [21], Diesel Index [25] and the HFRR lubricity measured by the correct diameter of the wear scar [2629].

The values obtained for the pure samples are shown in the table 1.

\section{Results and discussions}

\section{Comparing types of biodiesel}

As a result of analyzing the 3 different samples of biodiesel, synthesized by 2 different mixing methods, the following observations can be made:

-ultrasound blending is more dynamic than mechanical stirring; -blending at $37 \mathrm{kHz}$ frequency is more powerful than that of $80 \mathrm{kHz}$, which is more passive; that is why the biodiesel synthesized at $80 \mathrm{kHz}$ frequency needed more time, in this case double than that synthesized at $37 \mathrm{kHz}$;

-due to the violentintermixture of ultrasound cavitation, the separation of stages takes longer than $24 \mathrm{~h}$, occasionally taking even $48 \mathrm{~h}$ for a complete separation, at a room temperature of $22-25^{\circ} \mathrm{C}$. This is a disadvantage compared with mechanical blending where the settling finishes after $24 \mathrm{~h}$. For the biodiesel blended trough ultrasound, the settling time was influenced by the room temperature, the settling taking place within $10 \mathrm{~h}$ at $15^{\circ} \mathrm{C}$, but this was not the case for the mechanically stirred biodiesel.

- from the point of view of practical yield, ultrasound biodiesel at $37 \mathrm{kHz}$ frequency was close to that of the mechanically stirred biodiesel. The yield of the mechanically stirred biodiesel was $51 \%$, for ultrasound synthesized biodiesel at $37 \mathrm{kHz}$ frequency was $50 \%$, and for that synthesized at $80 \mathrm{kHz}$ frequency was $40 \%$. The yield was calculated taking into account the total of materials used for the synthesis of biodiesel, both oil and methanol, according to formula (1):

$$
\eta=\frac{\text { Final biodiesel }}{\text { oil }+ \text { methanol+catalyst }} \cdot 100
$$

where $\eta$ represents the yield;

- as for the physical properties shown in table 1 , mechanically stirred synthesized biodiesel had better results, compared with ultrasound synthesized biodiesel.

The influence of the three types of biodiesel on the final diesel-biodiesel blend

Relative density at $20^{\circ} \mathrm{C}$. Regarding density, shown in figure 1, it can be seen the addition of biodiesel creates a linear increase for density values.

Kinematic viscosity at $40^{\circ} \mathrm{C}$. The viscosity of the 36 blends, illustrated in figure 2, also knows a linear increase due to the added biodiesel. The biodiesel synthesized at 80 $\mathrm{kHz}$ frequency had occasionally lower values than those anticipated.

Flash point. The biodiesel synthesized at $80 \mathrm{kHz}$ frequency influenced negatively and unexpectedly the flash point, shown in figure 3 , decreasing even under the flash point of diesel, to $70^{\circ} \mathrm{C}$. Even though the flash point analysis had unexpected values, the linear increase is still present.

Aniline point, displayed in figure 4, knew a linear decrease due to the added biodiesel. The lower the aniline point, the lower the particulate emissions, which is a positive aspect. According to the standard ASTM D 611, if the aniline-sample mixture is miscible and clear at room temperature then 

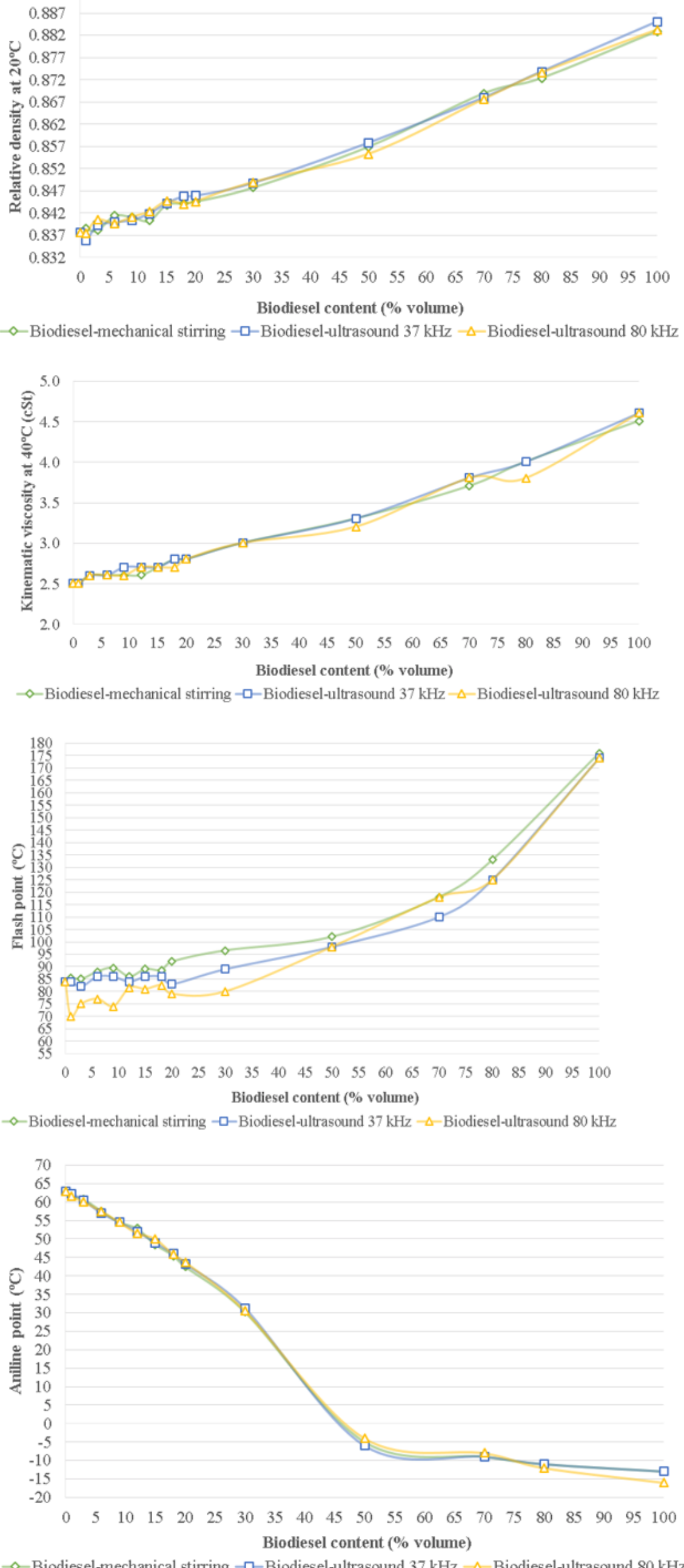

Fig. 1. Variation of relative density at $20^{\circ} \mathrm{C}$

Fig. 2. Variation of kinematic viscosity at 40 !

Fig. 3. Variation of flash point

Fig. 4. Variation of aniline point 


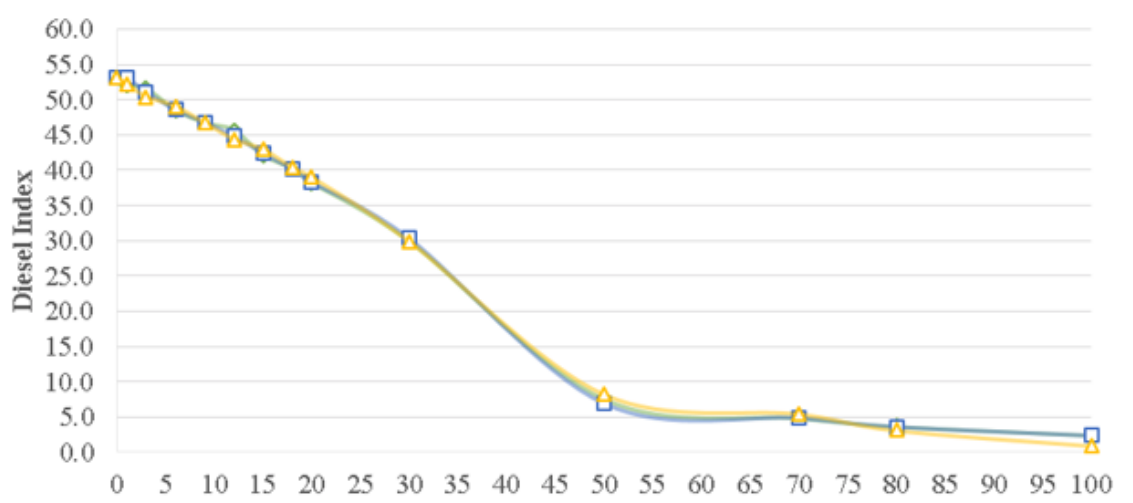

Fig. 5. Variation of Diesel index

Biodiesel content (\% volume)

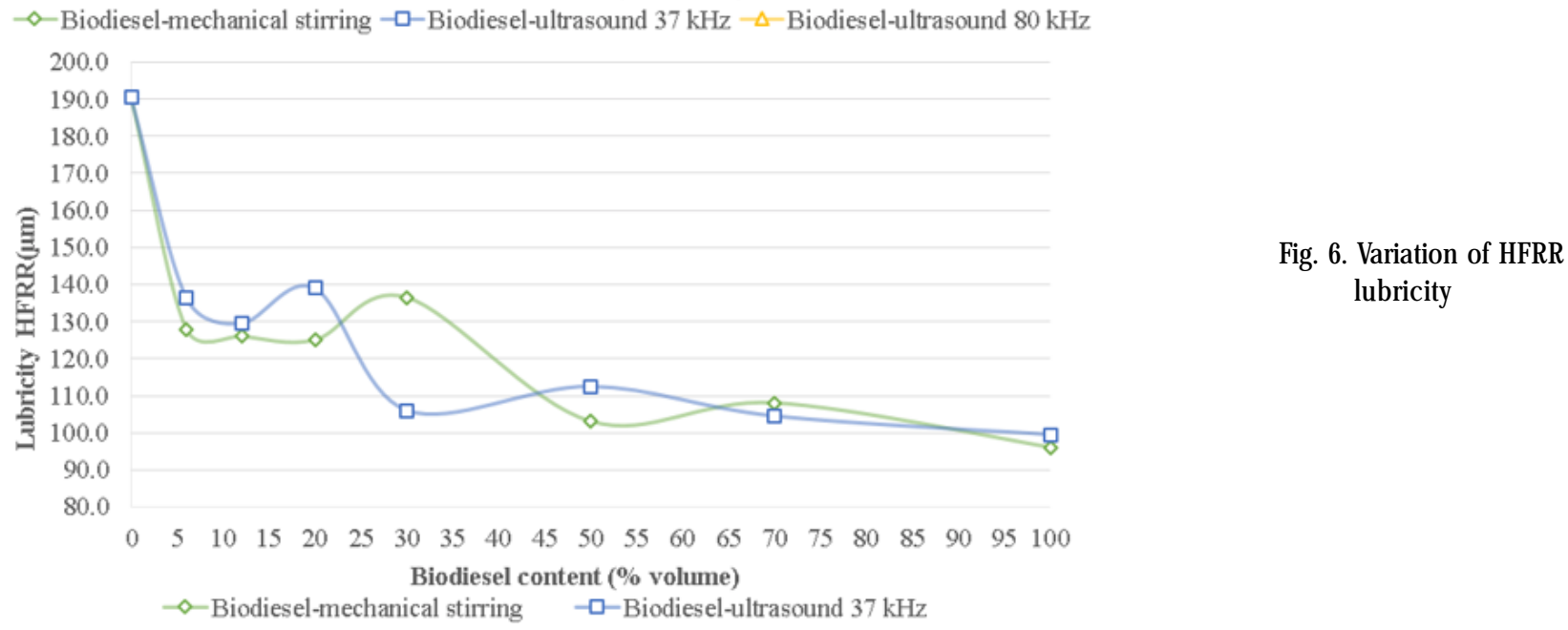

the aniline point will be determined by cooling the mixture with the help of the cryostat, leading to negative temperatures for blends having above $45 \%$ biodiesel.

Diesel Index, shown in figure 5, is an indicator of how diesel behaves inside the engine. The higher the value of the diesel index, the better the fuel behaves at self-ignition. The diesel index was calculated using the formula (2):

$$
D I=\frac{D \cdot A}{100}
$$

where DI is Diesel index;

$D=$ relative density of the sample at $20^{\circ} \mathrm{C}$, converted in API degrees;

$A=$ aniline point of the sample, converted in ${ }^{\circ} \mathrm{F}$.

As it can be seen in figure 5 the addition of biodiesel led to the decrease of the diesel index, due to the conversion of relative density in API degrees and the low point of aniline.

HFRR Lubricity. For this test the number of test samples was limited. Several samples meant to test lubricity were selected, with the following biodiesel percentages $0 \%$ (hydrofining diesel), $6 \%, 12 \%, 20 \%, 30 \%, 50 \%, 70 \%$, $100 \%$ (biodiesel). The blends between diesel and just two types of biodiesel were used: mechanical stirring type and ultrasound at $37 \mathrm{kHz}$ frequency type. Lubricity is the specific feature of this type of test, being represented by the corrected diameter of the wear scar. The results are shown in figure 6. Naturally, biodiesel improves lubricity, the corrected diameter of the wear having a linear decrease reported to the addition of biodiesel.

\section{Conclusions}

The purpose of this study was to compare the three original samples of biodiesel: mechanically stirred synthesized biodiesel and the two samples of biodiesel blended by using ultrasound cavitation at the two frequencies, $37 \mathrm{kHz}$ and $80 \mathrm{kHz}$. In case of ultrasound blending, the time necessary for synthesis decreased dramatically, from $2 \mathrm{~h}$ for mechanical blending, to $15 \mathrm{~min}$ for $37 \mathrm{kHz}$ frequency and $30 \mathrm{~min}$ for $80 \mathrm{kHz}$ frequency. However ultrasounds do have a downside regarding the time required for decanting, which increased from $24 \mathrm{~h}$ to almost 48. Still, this small inconvenient can be removed using a centrifugal to separate the stages. Regarding the yield, the biodiesel synthesized trough mechanical stirring had the biggest percentage: $51 \%$. This is followed by the biodiesel at $37 \mathrm{kHz}$ frequency with $50 \%$ and biodiesel at 80 $\mathrm{kHz}$ with $40 \%$. The biodiesel at $80 \mathrm{kHz}$ frequency has got the lowest yield because of the long time necessary for blending, $30 \mathrm{~min}$, which contributed to the losses during mixing, which were maximized due to the energetic ultrasound blending. Because blending at $80 \mathrm{kHz}$ frequency is more passive, synthesis of biodiesel in 15 min was not possible, transesterification being incomplete.

Regarding the physical properties studied, the three types of biodiesel have close characteristics, but the mechanically stirred biodiesel has the best features. The physical properties of the 2 biodiesel samples blended trough ultrasound cavitation, are almost the same, as shown in table 1, therefore it can be concluded that the only differences when comparing biodiesel synthesized by different ultrasound frequencies can be found in yield and the time required to mix the components. The behavior of biodiesel in the final blends had small variations, depending on the type of biodiesel used, but the results were close, too. The flash point was the only analysis where the biodiesel synthesized at $80 \mathrm{kHz}$ had a distortion, decreasing the flash point, instead of increasing it. Still, the linear increase that was normal for this kind of addition, was met in the end.

All studied properties are correlated with the added proportions of the biodiesel samples: density, viscosity, flash point, causing a linear increase with the biodiesel 
percentage, while aniline point, diesel index and lubricity caused a linear decrease reported to the increasing biodiesel percentage.

As a result of the studies, it was found that the biodiesel synthesized using ultrasound at $37 \mathrm{kHz}$ frequency could replace in the future the classically synthesized biodiesel, having similar characteristics and saving time during the blending process. For the moment the classical mechanical stirring method is the best choice, due to low costs regarding both equipment and maintenance.

\section{References}

1. JIAQIANG, E., PHAM, M., ZHAO, D., DENG, Y., LE, D., ZUO, W., ZHU, H., LIU, T., PENG, Q., ZHANG, Z., Renewable and Sustainable Energy Reviews, 80, 2017, p. 620

2. CHUAH, L.F., KLEMES, J.J ., YUSUP, S., BOKHARI, A., AKBAR, M.M., Journal of Cleaner Production, 146, 2017, p. 181

3. SALUJA, R.K., KUMAR, V., SHAM, R., Renewable and Sustainable Energy Reviews, 62, 2016, p. 166

4. HAJJARI, M., TABATABAEI, M., AGHBASHLO, M., GHANAVATI, H., Renewable and Sustainable Energy Reviews, 72, 2017, p. 445

5. SUBHEDAR, P.B., BOTELHO, C., RIBEIRO, A., CASTRO, R., PEREIRA, M.A., GOGATE, P.R., Ultrasonics Sonochemistry, 27, 2015, p. 530

6. SUBHEDAR, P.B., GOGATE, P.R., Ultrasonics Sonochemistry, 29, 2016, p. 67

7. BHANGU, S.K., GUPTA, S., ASHOKKUMAR, M., Ultrasonics Sonochemistry 34, 2017, p. 305

8. SANTIN, C.M.T., MICHELIN, S., SCHERER, R.P., VALÉRIO, A., LUCCIO, M.D., OLIVEIRA, D., OLIVEIRA, J.V., Ultrasonics Sonochemistry, 35, 2017, p. 525

9. SIVARAMAKRISHNAN, R., INCHAROENSAKDI, A., Bioresource Technology, 250, 2018, p.877

10. REFAAT, A.A., EL SHELTAWY, S.T., WIT Transactions on Ecology and the Environment, 109, 2008, p. 133

11. MASRI, A.N., ABDUL MUTALIB, M.I., AMINUDDIN, N.F., LEVEQUE, J.-M., Separation and Purification Technology, 196, 2018, p. 106
12. MARTINEZ-GUERRA, E., HOWLADER, M.S., SHIELDS-MENARD, S., FRENCH, W.T., GUDE, V.G., International J ournal of Energy Research, 42, no. 5, 2018, p. 1934

13. JOSHI, S.M., GOGATE, P.R., SURESH KUMAR, S., Chemical Engineering and Processing -Process Intensification, 124, 2018, p. 186 14. VELJ KOVIC, V.B., AVRAMOVIC, J.M., STAMENKOVIC, O.S., Renewable and Sustainable Energy Reviews, 16, no. 2, 2012, p. 1193 15. HO, W.W.S., NG, H.K., GAN, S., Applied Thermal Engineering, 100, 2016, p. 553

16. RAMACHANDRAN, K., SUGANYA, T., NAGENDRA GANDHI, N., RENGANATHAN, S., Renewable and Sustainable Energy Reviews, 22, 2013, p. 410

17. ALDHAIDHAWI, M., CHIRIAC, R., BADESCU, V., Renewable and Sustainable Energy Reviews, 73, 2017, p. 178

18. MAHMUDUL, H.M., HAGOS, F.Y., MAMAT, R., ADAM, A.A., ISHAK, W.F.W., ALENEZI, R., Renewable and Sustainable Energy Reviews, 72, 2017, p.497

19. SOMNUK, K., PRASIT, T., PRATEEPCHAIKUL, G., Energy Conversion and Management, 140, 2017, p. 91

20. SANDRU, S., CURSARU, D., ONUTU, I., STANICA EZEANU, D., Bulletin of Romanian Chemical Engineering Society, 3, no. 1\&2, 2016, p. 68

21. GULUM, M., BILGIN, A., Fuel Process Technol., 134, 2015, p. 456

22. GULÜM, M., BILGIN, A., Fuel, 199, 2017, p. 567

23. GULÜM, M., BILGIN, A., Fuel Process Technol., 149, 2016, p. 121

24. POMENIÆE, L., JURAC, Z., Archives of Materials Science and Engineering, 62, no. 2, 2013, p. 73

25. KANAVELI, I.P., ATZEMI, M., EVRIPIDIS, L., Fuel, 199, 2017, p. 248 26. SUNDUS, F., FAZAL, M.A., MASJUKI, H.H., Renewable and Sustainable Energy Reviews, 70, 2017, p. 399

27. CURSARU, D., TANASESCU, C., Rev. Chim.(Bucharest), 63, no. 8, 2012, p. 835

28. DRAGOMIR, R.E., OPRESCU, E. E., RO $\cong$ CA, P., Rev. Chim. (Bucharest), 66, no. 3, 2015, p. 400

29. ONUTU, I., PANTEA, O., ION, S., Journal-Balkan Tribological Association, 12, no. 2, p. 212

$\overline{\text { Manuscript received: } 30.05 .2018}$ 